\title{
Akut és szubakut klinikai állapotok radiológiai intervenciója: fókuszban a nem vascularis intervenciók és a haemoptysis kezelése
}

\author{
Nemes Balázs dr. ${ }^{1}$. Doros Attila dr. ${ }^{2}$ \\ Semmelweis Egyetem, Általános Orvostudományi Kar, ${ }^{1}$ Városmajori Szív- és Érgyógyászati Klinika, \\ ${ }^{2}$ Transzplantációs és Sebészeti Klinika, Budapest
}

\begin{abstract}
Az intervenciós radiológia módszerei gyors, egyszerű és kevéssé megterhelő megoldásokat kínálnak akut és szubakut helyzetekben is. Nem vascularis intervenciók körébe tartoznak a folyadékgyülemek aspirációja, drenázsa, az epeúti intervenciók egy része, a percutan nephrostoma behelyezése és a bélpasszázs átmeneti helyreállítása is. Ebben az összefoglalóban a szerzők részletesebben foglalkoznak a szintén akutan kezelendő haemoptysis intervenciós radiológiájával is. Az esetek jelentős részében a beavatkozások 12-24 órán belül elvégzendők, amelyhez ideális esetben a hét minden napján 24 órában szolgáltatást nyújtó, speciális tudással és felszereléssel rendelkező és megfelelően finanszírozott centrumok biztosítanak hátteret. A szakmák közötti konzultáció, együttmúködés, a megfelelő indikációs konszenzus és a strukturált oktatás teszi igazán effektívvé az ilyen, még kialakításra váró centrumok múködését. Orv. Hetil., 2015, 156(17), 687-695.
\end{abstract}

Kulcsszavak: intervenciós radiológia, drenázs, biliaris intervenció, endourológia, gastrointestinalis stent, haemoptysis, embolisatio

\section{Acute and subacute clinical situations managed by interventional radiology: Focus on non-vascular interventions and treatment of hemoptysis}

\begin{abstract}
Interventional radiology provides fast, straightforward and tolerable solutions for many medical problems including acute and subacute situations. Aspiration and drainage of fluid collections, biliary and endourologic interventions and gastrointestinal interventions are parts of non-vascular interventions. In addition, the authors discuss in detail interventional radiological treatment options in patients with hemoptysis. In acute cases interventions must be performed within 12-24 hours. For background, an everyday 24 hours service should be provided with well-trained personnel, high quality equipment and devices, and a reasonable financial reimbursement should be included, too. Multidisciplinary teamwork, consultations, consensus in indications and structured education should make these centers function most effectively.
\end{abstract}

Keywords: interventional radiology, drainage, biliary intervention, endourology, gastrointestinal stent, hemoptysis, embolization

Nemes, B., Doros, A. [Acute and subacute clinical situations managed by interventional radiology: Focus on non-vascular interventions and treatment of hemoptysis]. Orv. Hetil., 2015, 156(17), 687-695.

(Beérkezett: 2015. február 6.; elfogadva: 2015. február 21.)

Rövidítések

$\mathrm{ABE}=$ arteria bronchialis embolisatio; $\mathrm{AVM}=$ arteriovenosus malformatio; $\mathrm{BA}=$ bronchialis artéria; $\mathrm{DSA}=$ digitális szubtrakciós angiográfia; ERCP = endoszkópos retrográd cho- langiopancreatographia; MDCTA = multidetektoros CT-angiográfia; $\mathrm{nBCA}=\mathrm{n}$-butil-cianoakrilát; $\mathrm{PTC}=$ percutan transhepaticus cholangiographia; PTD = percutan transhepaticus drenázs; PVA = polivinil-alkohol 
Összefoglalónk szubjektív választás alapján emeli ki az akut és szubakut helyzetben alkalmazandó radiológiai intervenciók közül a nem vascularis intervenciókat és a haemoptysis kezelését - ezzel egy időben felhívva a figyelmet arra a tényre, hogy a lapszám többi dolgozatában tárgyalt beavatkozások jelentôs részét szintén alkalmazzuk akut és szubakut szituációkban.

Nem vascularis intervencióknak nevezünk minden olyan radiológiai beavatkozást, amely nem az erekkel, erekben vagy az erek betegségeivel foglalkozik. Akut szituáció esetén tályogok, illetve az epeutak és a vizeletelvezető rendszer eltérései a legfontosabb indikációk.

A vérköpés nehezen kezelhető, akár az életet is veszélyeztető állapot. A masszív tüdővérzés nagy mortalitású, és mihamarabbi beavatkozást igényel. A diagnosztikai lehetőségek a mellkasröntgentől az invazív bronchoszkópiáig terjednek, azonban a multidetektoros CT-angiográfia (MDCTA) a vérzés lokalizációján túl az azt okozó folyamat azonosítását, valamint az azt ellátó artériákat is azonosítani képes. Az arteria bronchialis embolisatiója (ABE) jelenleg a leghatásosabb terápiát jelenti ezekben az esetekben.

\section{Akut és szubakut nem vascularis radiológiai intervenciók}

\section{Folyadékgyülemek aspirációja, drenázsa}

A test bármely részében kialakulhat befertőzött folyadékgyülem, amely akár nyilvánvalóan, akár rejtetten gócként, szeptikus állapot okozójaként lehet jelen. Képalkotó diagnosztikai eszközeink fel tudják kutatni a gyanús folyadékokat, de vannak információk, amelyeket pusztán a képekből, echogenitásból, denzitásból, jelintenzitásból, kontrasztanyag-felvételből nem tudunk megmondani. A folyadékgyülemek aspirációjának kettős a célja: mintát venni a folyadékból; az analízis során a kémiai laboratóriumi vizsgálat meg tudja mondani, milyen anyag, molekula van a folyadékban, hogy tartalmazhat-e vizeletet, epét stb. A folyadékból nyert kenetből közvetlenül láthatóvá válhatnak például gombák, míg néhány napos tenyésztés után gombák, aerob és anaerob baktériumok és azok antibiotikum-rezisztenciája is megadható. A minél előbb megkezdett célzott antibiotikus kezelés a leghatékonyabb és leggazdaságosabb gyógymód.

Itt érdemes részletezni a biztonságos szúrás kritériumait. Elsősorban szükség van egy korrekt indikációra, amelyet lehetőleg multidiszciplináris team állítson fel. A beavatkozást végző radiológus véleménye kritikus ilyen esetekben, hiszen a biztonságos szúrásirányt ő határozza meg. A beteget és/vagy hozzátartozóját tájékoztatni kell és beleegyezését el kell nyerni. Minden egyes invazív diagnosztikai beavatkozás megköveteli a vérkép és az alvadási paraméterek ismeretét, szükség esetén korrekcióját [1]. Hígabb folyadékból vékonyabb (21-23 G) tûvel, súrúbb folyadékból vastag (17-20 G) tûvel nyerhetünk elegendő anyagot további vizsgálatra. Sưrübb folyadék aspirációját segíti a „cameco” biopsziás eszköz, illetve a beszúrt Chiba, vagy trokárrendszerú tû végéhez illesztett műanyag cső, ami segítheti a tú pozícióban tartását a beavatkozás alatt. A beavatkozás biztonságos, a minor szövődmények $1 \%$ alattiak, major szövődmények közül a vérzés és a szepszis csak esetenként fordulnak elő. Sokak által ajánlott és általunk is gyakorolt taktika, hogy ha a punkció során infektált folyadék ürül, és nincs kontraindikációja, Seldinger-módszerrel, 5-7 F-es drént is bevezetünk, amelyen a folyadékgyülem biztonságosan eltávolítható, az üreg öblíthető, átvezetve az invazív diagnosztikát a radiológiai intervencióba, illetve terápiás beavatkozásba.

Percutan drenálás - Seldinger- vagy trokármódszerrel - csaknem minden olyan elváltozás esetén lehetséges, ami biztonságosan elérhető, megszúrható és valamelyik arra alkalmas képalkotó módszerünkkel ábrázolható, és ezáltal a tú útja megtervezhető, illetve követhető. Általánosságban javasolható, hogy a trokármódszert a felszínesebb nagy folyadékgyülemek, tályogok drenázsára használjuk, mert bár a módszer gyors és egyszerú, de traumatikus is. A behelyezett drén mérete trokármódszerrel 5-8 F lehet (esetenként ennél jóval nagyobb is), míg Seldinger-módszerrel szinte bárhova drént vezethetünk, a járattágítás után az elérhető legnagyobb méretekben (általában 12-14 F) (1. ábra). Nem szerencsés azonban nagyméretú drént átvezetni parenchymás szerveken, ereken és a béltraktuson - bár ez ma már nem tekinthető kontraindikációnak. Legfontosabb kontraindikációk: az indikáció hiánya; ha nincs lehetőség (módszer, megfelelő eszköz) a beavatkozás biztonságos kivitelezésére és a nem korrigálható alvadási zavar. Meg kell említeni, hogy bizonyos esetekben a percutan drenázstól nem várható jó eredmény, legfeljebb az akut tünetek megszüntetése után a definitív kezelésig, palliatív céllal végezzük el [2]. Ilyen a Crohn-betegség miatt kialakult tályogok kezelése, az infektált haematomák, necroticus és infektált tumorok drenálása. Problémát jelent a multilocularis tályogok drenázsa is, illetve pancreatitis után hónapokig húzódó kezelésre kell számítani [3].

A folyadékgyülemek drenázsához tartozik még az epehólyag percutan drenázsa is, amely szintén végezhető trokár- vagy Seldinger-módszerrel, a máj parenchymáján keresztül. Indikációja az empyema, a szeptikus állapotot okozó cholecystitis rossz állapotú, gyakran idős betegek esetében - elfogadható alvadási paraméterek mellett. A fertőzött epe eltávolítása után a betegek stabilabb állapotba kerülnek, és ha szükséges, a későbbiekben elektív mütét végezhető [4].

\section{Biliaris intervenciók}

Seldinger-módszert használhatunk az epeutak elzáródásának kezelésekor is. A terápia elsősorban a szintén minimálisan invazív endoszkópia (ERCP). Percutan beavatkozásra (PTC, PTD) akkor kerül sor, ha az endoszkópia sikertelen vagy nem lehetséges. Többé-kevésbé alkal- 


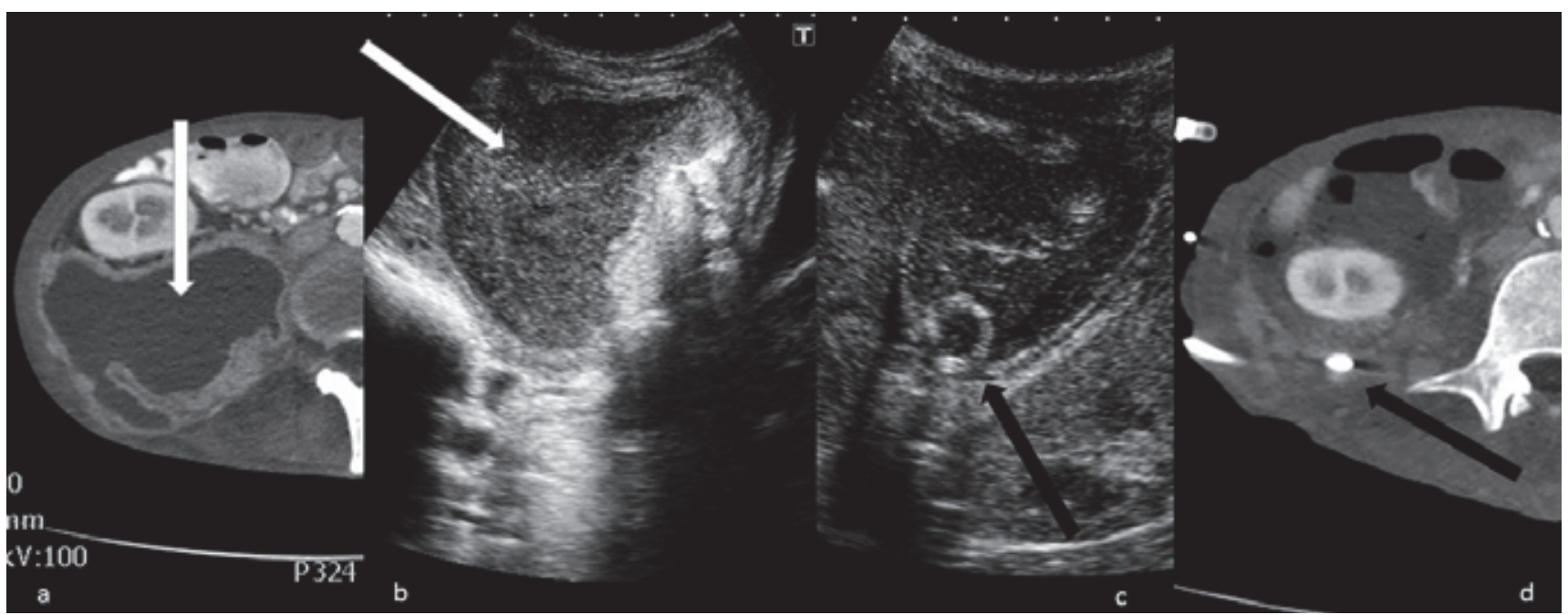

1. ábra

Súlyos állapotú beteg ultrahangvezérelt tályogdrenázsa. a) Kontrasztanyagos CT-vizsgálat a jobb retroperitonealis régióban mutat kiterjedt tályogot (fehér nyíl). b) Ultrahangvizsgálat mutatja a tályogot (fehér nyíl), vastag fallal és sűrű bennékkel. c) Tályogdrenázs végén ultrahanggal jól átható a behelyezett pigtail drén (fekete nyíl). d) Kontroll-CT-vizsgálaton a kiürült üregben látható a drén egy része (fekete nyíl)

mazható az a taktika, hogy a distalis, a ductus hepatocholedochust érintő kóros állapotok inkább az ERCP hatáskörébe tartoznak, míg a többszörös hilaris folyamatok inkább PTD-vel kezelhetők jobban. Az elzáródáson kívül eredményesen tudjuk kezelni a cholangitist és a iatrogén vagy traumás sérüléseket is. Az elzáródások elsősorban malignus folyamatok következményei, de posztoperatív szúkületek, sludge és kövek is kezelhetók, valamint olyan ritkább betegség okozta szúküuletek és a következményes gyulladás, mint a progresszív szklerotizáló cholangitis. A fenti indikációk közül kuratívnak csak a sérülések és posztoperatív szúkületek kezelése, valamint a kövek és sludge eltávolítása, a cholangitis miatt kialakult szeptikus állapot kezelése tekinthető. A beavatkozást megfelelő indikáció felállítása és a beteg előkészítése előzi meg (mint minden más esetben is), és célszerü széles spektrumú antibiotikumot adagolni. A beteget és hozzátartozóját tájékoztatni kell, és alá kell íratni a beleegyezô nyilatkozatot. Megfelelő véna biztosítása, lassú cseppszámú infúzió és adekvát monitorozás javasolt. A beavatkozásokat több helyen csak helyi érzéstelenítésben végzik, de a világ fejlettebb felén az éber szedáció fentanyl és midazolam adásával - terjedt el, esetenként vénás altatás vagy általános anesztézia lehet indokolt. Mindezt egybevéve, a leghatékonyabb és a beteg érdekeit legjobban szolgáló módot kell választani.

A percutan epeúti intervenciók akut indikációi az életet közvetlenül veszélyeztető progresszív icterus, a szeptikus állapotot okozó cholangitis (idős vagy rossz állapotú betegnél a cholecystitis, empyema is), progresszív biloma, insufficientia, biliogén tályog. A feladat első lépésben a szepszisforrás szanálása: a tályogok, bilomák, az epehólyag percutan drenázsa - a lehető legegyszerúbb, legkevésbé traumatikus és leghatékonyabb módon. Kihívást jelenthet az insufficientia kezelése, mivel ilyen eset- ben - és néha cholangitisek esetén - az epeutak nem tágabbak. Minden akut indikációval végzett beavatkozásnál a Seldinger-módszer javasolt - lehetőleg vékony tûvel, koaxiális introducer set alkalmazásával. A trokárbehatolási mód roncsoló, több kisérsérüléssel, így bakteriális kontaminációval jár. Kivételt jelenthetnek azok a folyadékgyülemek, amelyek felszínesek, közvetlenül szúrhatók. Nem tág epeutak esetén a punkciós kísérletek számát limitálni célszerû - 5-6 sikertelen, vékony tûs szúrási kísérlet után a beavatkozás feladható -, a szepszis és a gyakori centrális érsérülések súlyosbíthatják a beteg állapotát.

Sikeres punkció, drenázs esetén mindenekelőtt az epe, a folyadék leszívása szükséges, és a kontrasztanyag menynyiségét is korlátozzuk - a túlnyomás a szeptikus sokk kockázatát növeli. Az eltávolított folyadékból tenyésztést indítunk a későbbi célzott antibiotikus kezelés előkészítésére. Első lépésben 7-8 F-es drén bevezetése elegendő lehet az epeutakba, de tályogok, bilomák drenázsára nagyobb, 8-12 F átmérőjú katéterek ajánlottak, a járat megfelelő előtágítása után (2. ábra). Nem kell törekedni a pontos anatómiai viszonyok, illetve a kiváltó ok tisztázására - ezt megtehetjük akkor, amikor a drenázs segítségével az akut tünetek elmúltak (kivéve: insufficientia). A drenázskatéter rögzítése, a beteg monitorozása, fektetése, a drén öblítése, a kontroll és további intervenciók, konzultációk megszervezése, időzítése az intervenciós radiológus feladata, a kezelő osztályos orvossal együttmúködve [5].

\section{Urogenitalis percutan intervenciók}

A korábban már tárgyalt beavatkozásokhoz nagyon hasonló a vizeletelvezető rendszer gyulladásos és obstruktív folyamatainak percutan kezelése. Kő, daganat, komp- 


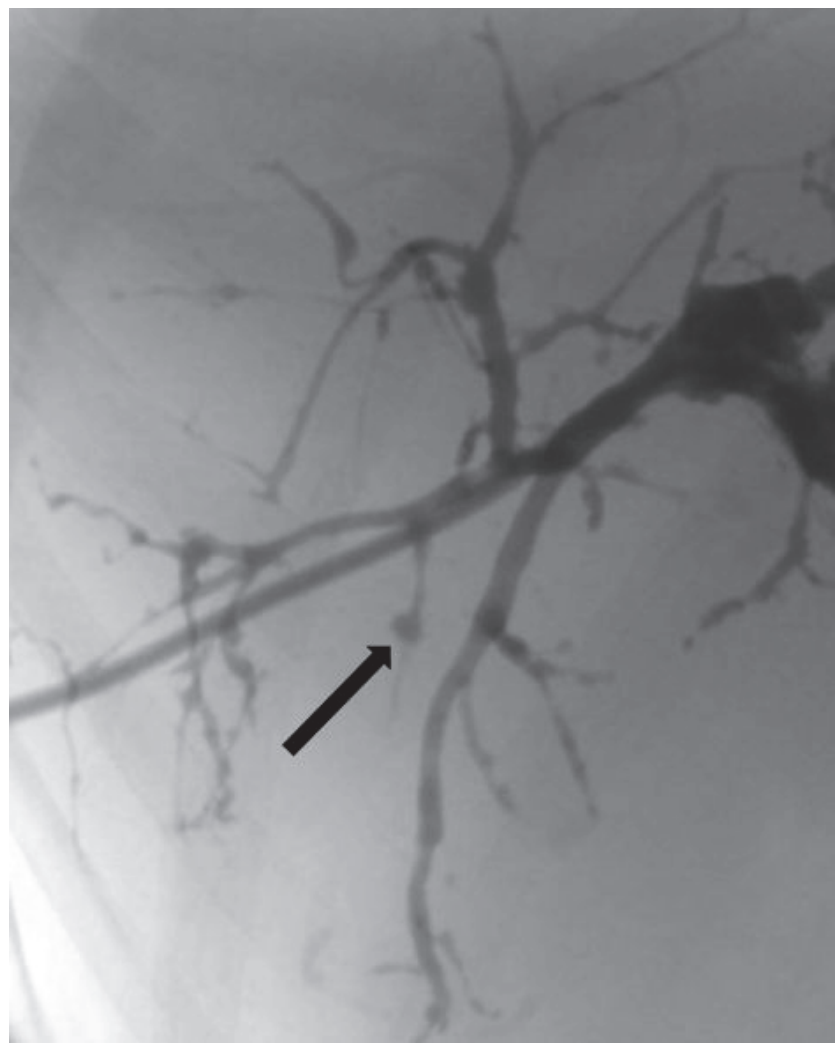

2. ábra

PTD akut cholangitis és icterus esetében. A cholangiographián mikrotályogok telődése (fekete nyíl) figyelhető meg. Külső drenázs fenntartása és antibiotikus kezelés alkalmas az akut tünetek kezelésére resszió, iatrogén obstrukciók felülfertőződéssel szövődve súlyos gyulladást és szepszist okozhatnak. A retrográd endourológiai módszerek - cisztoszkópia, kőextractio, ureterkatéter és stentbehelyezés - hagyományosan az urológusok feladata. Amennyiben ezek a lehetőségek nem adottak vagy sikertelenek, a tágult üregrendszer percutan drenázsa végzendő el. Az akut állapot elmúlása után a behelyezett drén járata olyan kapuként szolgál majd, amelyen a legtöbb radiológiai és urológiai intervenció elvégezhető. Az üregrendszer szúrása ma már ultrahang segítségével történik, általában dorsolateralis irányból, de az ultrahang rugalmassága más irányokat is megenged. Nagyon kell ügyelni arra, hogy a parenchymán keresztül az általában jól látható kehelytalpakat kell megszúrni, lehetóleg merólegesen, mivel a nagyobb erek sérülése így kerülhető el a legjobban. Primer drenázsra 7-8 F-es katéterek elegendőek, de nagyon sürü tartalom vastagabb katéteren tud csak távozni. A fentiekhez hasonlóan először az akut állapot kezelésére szorítkozunk, a pontos anatómiai ábrázolás, netán végleges megoldás későbbi időre halasztható (3. ábra). Uretersérülések esetén a pyelon leggyakrabban nem tágabb - ez nehezíti a punkciót, de jó minőségű ultrahang-berendezéssel és ultrahangon jobban látható végkiképzésű tűvel sikeresen kivitelezhető [6].

A perinephricus, psoas és kismedencei folyadékok, urinomák, tályogok drenázsa nem különbözik a korábban leírtaktól.

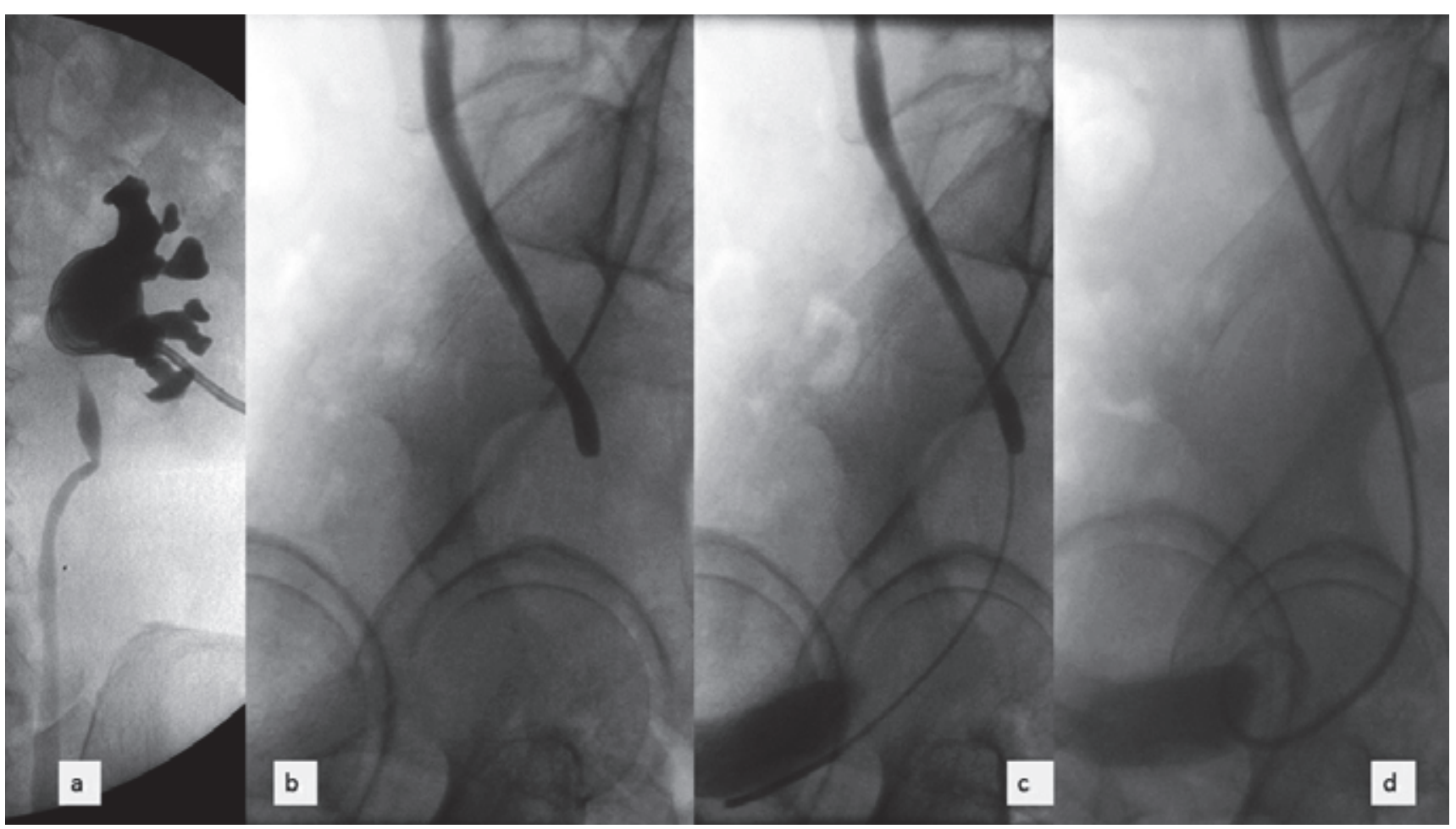

3. ábra $\quad$ Irradiáció után kialakult ureterelzáródás, amelyet retrográd úton nem sikerült rekanalizálni. a) Percutan nephrostoma feltöltése. b) Félferde felvételen a kismedencei szakaszon elzáródás látható. c) Sikeres anterográd rekanalizáció. d) Dupla „J” végú ureterstent caudalis vége látható a hólyagban 


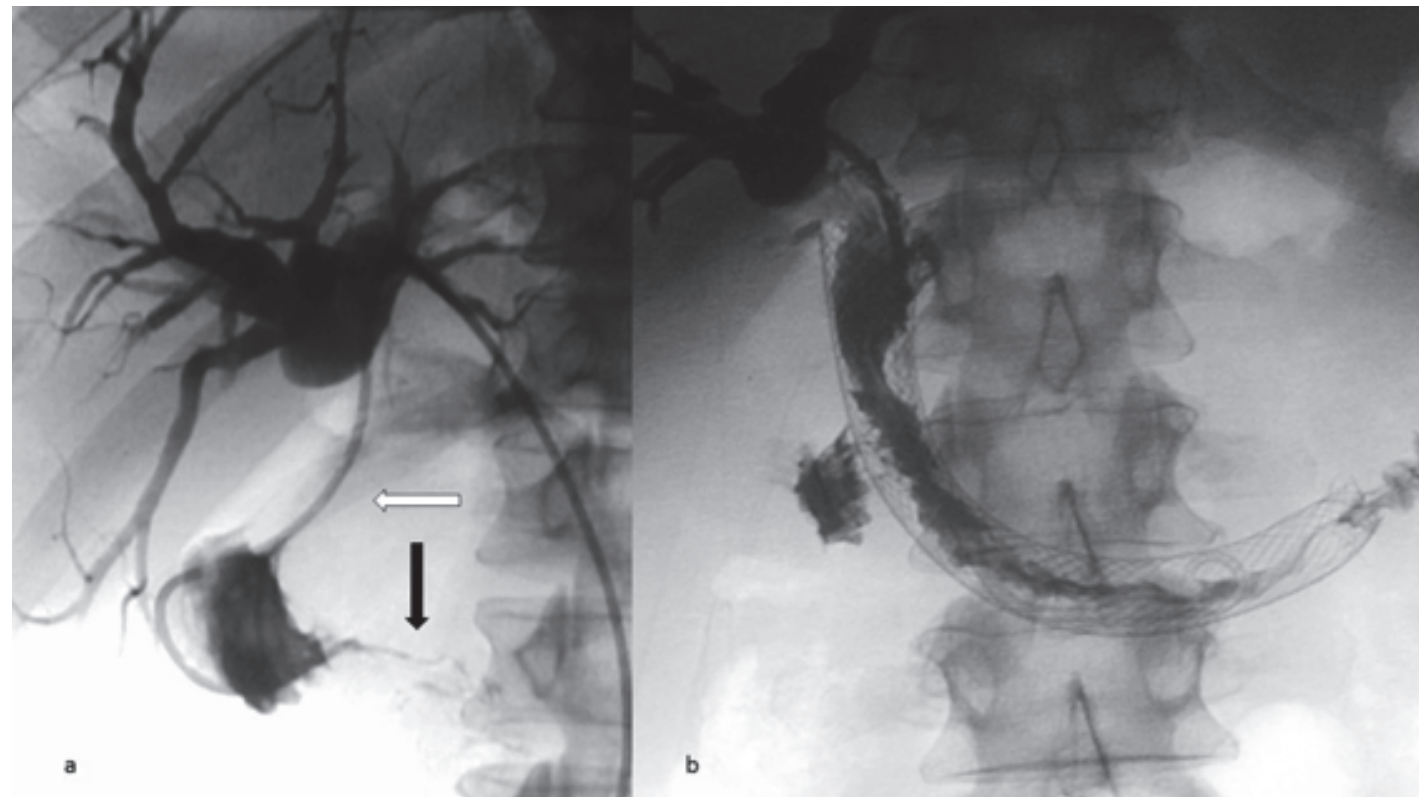

Pancreasfejtumor okozta duodenumszúkület miatt korábban gastrojejunostomia történt. Icterus miatt PTD-t végeztünk. a) A cholangiographiával a ductus choledochus (fehér nyíl) és a duodenum (fekete nyíl) szúkülete ábrázolódik. b) A behelyezett nagyméretű öntáguló fémstent az epevezeték és a duodenum szúkületét egyaránt áthidalja

\section{Gastrointestinalis passzázszavarok intervenciós radiológiai kezelése}

$\mathrm{Az}$ intervenciós radiológia szerepe a gastrointestinalis kórfolyamatok kezelési ideológiájában nem különbözik a korábban tárgyalt indikációktól: kis megterheléssel olyan alternatív - palliatív vagy kuratív - kezelést tudunk nyújtani, amelyek alternatívái a sebészi és endoszkópos módszereknek. A kuratív módszerek között megemlíthető a diverticulitis talaján kialakult tályog drenázsa, amely lokalizált peritonitis esetén is alkalmazható. A palliatív kezelések közé tartozik a distalis colon obstrukcióinak rectalis katéterezés útján történő stentelése, illetve a felső gastrointestinalis traktus - oesophagus, gyomor, duodenum és jejunumkacsok (utóbbi fóleg biliodigestiv anastomosisok után) - transbiliaris vagy transnasalis áthidalása, stentelése (4. ábra). Mindkét esetben a mütéti mortalitás és morbiditás csökkentése a legnagyobb előny, esetenként sebészi vagy endoszkópos kezelés nem is lehetséges. A gastrointestinalis obstrukciók stenteléséhez nagyméretü öntáguló fémstenteket (fedett stenteket is), újabban benignus szúkületeknél biodegradábilis stenteket használunk. A passzázs helyreállítása a beteg állapotának gyors javulásához vezet, lehetővé téve a kiváltó ok elektív kezelését vagy az alapbetegség további, például onkológiai terápiáját. Szintén a beteg állapotának javítását szolgálják a táplálást elősegítő szondák. Dedikált, bőrön át behelyezhető horgonyokkal ellátott készletek állnak rendelkezésre a percutan gastrostomiák és gastrojejunostomiák bevezetéséhez. Hasonló módon alkalmazható a percutan coecostomia, indikációi a megacolon és ehhez hasonló funkcionális colectasiák $[7,8]$.

\section{Intervenciós radiológia haemoptysisben}

A masszív vérköpés definíciója nem egységes, de leggyakrabban $250-500 \mathrm{ml}$ vérzést jelent 24 órán belül, esetenként a több mint három egymást követő napon előforduló, alkalmanként $100 \mathrm{ml}$-t meghaladó vérzést is masszívnak nevezik $[9,10,11]$. A masszív vérzés az alveolaris térben a gázcserét akadályozva okozhat halált.

A konzervatív kezelés nagy mortalitással (50-100\%) jár [9]. A korábban egyetlen terápiás lehetőséget jelentő sebészeti beavatkozás a betegek jelentős részében a komorbiditás, illetve a csökkent légzési rezervkapacitás miatt komoly kockázattal járt (mortalitás 7-18\%), a sürgősségi műtétek mortalitása elérheti a 40\%-ot [12]. Az arteria bronchialis embolisatio minimálisan invazív terápia, amely a masszív és rekurrens vérzés kezelésének hatékony nem sebészi alternatíváját jelenti.

\section{Patofiziológia}

A ritkán előforduló mellkasi nagyérbetegségektől eltekintve a vérzés leggyakrabban a bronchialis artériákból ered. A tüdő kettős vérellátását a pulmonalis és a bronchialis artériák adják. A keringés 99\%-át a gázcserét biztosító pulmonalis artériás rendszer biztosítja, 1\% jut a bronchialis artériákra. A két rendszert számos anastomosis köti össze. Azokban az esetekben, amikor a pulmonalis keringés lokális zavara áll fenn, a bronchialis artériák proliferálnak és kitágulnak [13]. Hasonló elváltozások alakulnak ki krónikus gyulladások esetében is [14]. A neovascularisatio során kialakuló vékony falú erek a visszatérő infekció miatt, illetve magas szisztémás vérnyomásnak kitéve könnyen megrepednek és a vér a légutakba jut. 


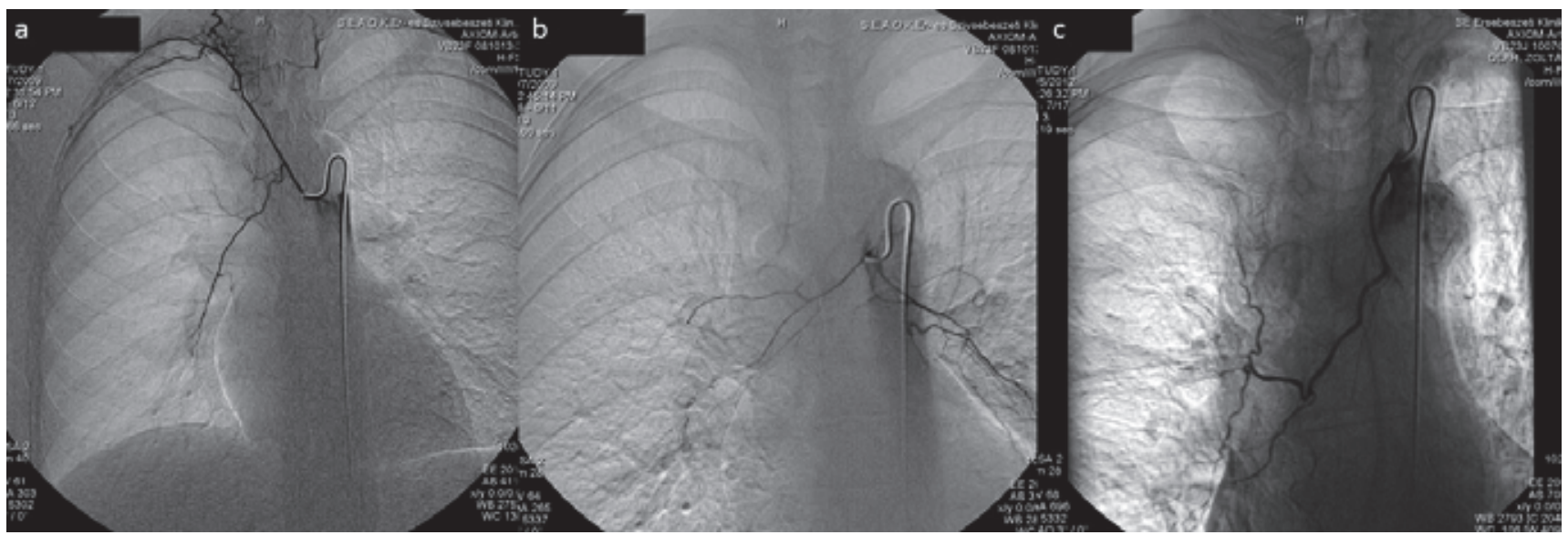

5. ábra

a) Jobb oldali intercostobronchialis artéria. b) Együtt eredő kétoldali bronchialis artéria. c) A bal arteria subclaviából eredő ectopiás jobb arteria bronchialis

A patológiás alapfolyamat leggyakrabban bronchiectasia, aspergilloma, tuberculosisos üreg, bronchogen tumor vagy krónikus obstruktív tüdőbetegség. Ritkábban congenitalis szívbetegség, mellkasi nagyérbetegség és AVM lehet az ok. Fiatal betegek esetében a cisztás fibrosis okozhat leggyakrabban vérköpést.

A diagnosztikus vizsgálatok célja a vérzés lokalizációja és okának felderítése. A mellkasröntgen az oldal meghatározásánál sokkal többet nem nyújt. A bronchoszkópia szintén a vérzés oldalának, esetenként szegmensszintü lokalizációjában segíthet. A CT-vizsgálat a korábban említett információkat jó hatásfokkal biztosítja. Az MDCTA ezeken túl a vérzést okozó bronchialis vagy szisztémás artériák felderítésében is hatékonyabb a hagyományos angiográfiánál [15]. Többsíkú rekonstrukciók segítségével a hagyományos angiográfiánál pontosabb vizsgálómódszer, lehetőséget ad a bronchialis artériák eredésének pontos meghatározására és a vérzést okozó nonbronchialis artériák megtalálására.
A bronchialis artériák anatómiája sok variációt mutat, jobb oldalon az ér az intercostobronchialis törzsből ered és caudal felé fut a jobb főhörgő mentén. Emellett esetenként distalisabban még egy jobb oldali artéria eredhet. Bal oldalon egy vagy két bronchialis artéria ered az aortából. Jellemzően mindegyik bronchialis artéria a bronchialis rendszerrel párhuzamosan fut. Ectopiás bronchialis artéria eredhet az aortaívből, a hasi aortából, a truncus brachicephalicusból, arteria subclaviákból, illetve azok ágaiból (5. ábra). A két milliméternél nagyobb átmérőjű bronchialis artéria kórosnak nevezhető és embolisatiója elvégzendő.

Krónikus gyulladásos folyamat esetében szisztémás kollaterálisok alakulhatnak ki, amelyek transpleuralisan haladnak és nem társulnak a bronchialis rendszerhez (6. ábra). A vérzésforrásként azonosítható szisztémás artériák felkeresése és azonosítása lényegesen nehezebb feladat, és mint említettük, az MDCTA-vizsgálat nagy segítséget nyújt ebben. A nonbronchialis kollaterálisokat

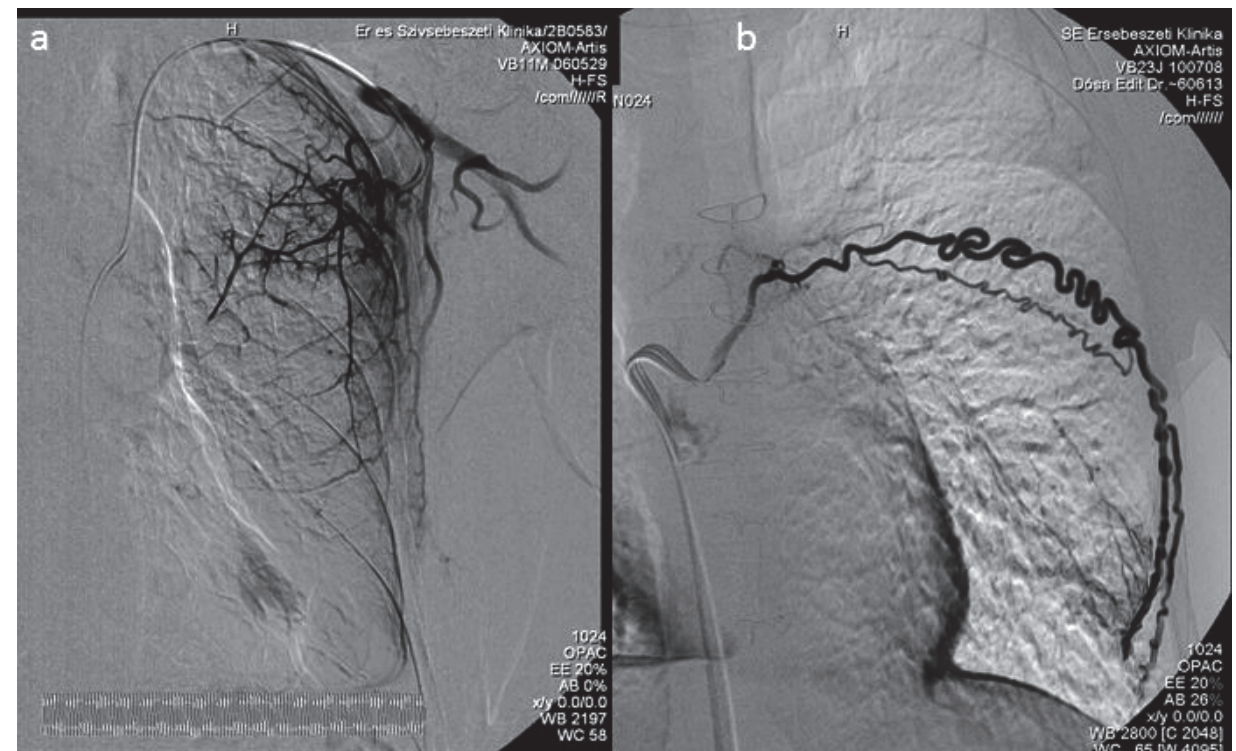

\begin{tabular}{l|l} 
6. ábra & a) Az arteria axillaris mellkasfali ága felól kialakult söntön keresztül telődik egy pulmonalis artéria. b) Hipertrofizált bronchialis artéria tölti a bal alsó
\end{tabular} lebenyi pulmonalis artériát 
a hipertrofizált bronchialis artériákkal együtt embolizálni kell.

$\mathrm{Az}$ embolisatio során figyelmet kell arra fordítani, hogy a gerincvelő vérellátását biztosító medullaris artériákat azonosítsuk és elkerüljük. A közülük legerősebb Adamkiewicz-artéria az alsó mellkasi intercostalis artériákból ered, azonban ritkán a jobb oldali intercostobronchialis artériából is eredhet medullaris ág. A transversalis myelitis elkerülése érdekében ilyen esetekben az eredéstől distalisan mikrokatéteres technikával óvatosan kell a bronchialis embolisatiót végezni. A beavatkozás előtt alaposan fel kell térképezni az embolizálandó erek esetleges kollaterális összeköttetéseit más érterülettel.

\section{Arteria bronchialis embolisatio (ABE)}

Az embolisatio előtt készített mellkasi aortográfiás DSAképen felmérhető a bronchialis artériák eredése és az esetleges szisztémás kollaterálisok jelenléte. Az artériák szelektív katéterezésével azonosíthatók azok az eltérések, amelyek patológiás érstruktúrára utalnak: hipertrofizált, kanyargós bronchialis artériák, bronchopulmonalis sönt, hypervascularizált érterület, extravasatio (7. ábra).

Amennyiben nem találunk kóros bronchialis artériákat, a korábban említett nonbronchialis artériák felkeresése és katéterezése szükséges. Elsősorban az intercostalis artériák, az arteria subclaviák és az arteria phrenica inferior vizsgálandók.

Az embolisatio célja a vérnyomás csökkentése a sérülékeny patológiás erekben. Az embolisatiós anyag kiválasztásakor ügyelni kell arra, hogy az a bronchopulmonalis összeköttetéseken ne juthasson át, mert pulmonalis infarktust vagy nagyvérköri embolisatiót okozhat. A bronchopulmonalis anastomosisok legnagyobb átmérője 325 um [16], ezért ennél nagyobb átmérőjű részecskék használatosak. A leggyakrabban és általunk is használt embolisatiós anyag a polivinil-alkohol (PVA), amelyból a 350-500 $\mu \mathrm{m}$ átmérőjüt alkalmazzuk. A PVA szabálytalan alakú és az adott mérethatáron belüli átmérővel bíró, fel nem szívódó részecskékből áll. Hátránya, hogy hajlamos az összetömörülésre a katéterben, főleg a mikrokatéterekben. Ugyanezen tulajdonsága miatt nem tud eljutni az azonos átmérőjű kiserekig, mivel összetömörülve azoktól proximalisabban elakad. Az utóbbi ok miatt használatosak a mikrogyöngyök, amelyek hidrofil bevonatú uniform méretú részecskék. Az irodalomban leírták az N-butyl cyanoacrylate (nBCA) használatát is, azonban ezzel még csak kevés tapasztalat van, használata megfelelő jártasságot igényel a distalisabb embolisatio, valamint a szövetnecrosis nagyobb veszélye miatt [17, 18]. Embolisatiós spirálok használata azért korlátozott, mert azok méretük miatt csak a proximalis érszakaszokba juttathatók el és ismételt vérzés esetén lehetetlenné teszik a distalis érterület újabb embolisatióját. Ebben az esetben a spirál mögötti kollaterálisok fenntarthatják a vérzést, azonban azok elérése sokkal nehezebb, mint a már kitágult bronchialis artériáké. A kisméretü artériák szuperszelektív embolisatiója csak koaxiális mikrokatéterekkel végezhető. A katéteres manipulációt megfelelő óvatossággal kell végezni, mivel spasmus esetén a beavatkozás meghiúsulhat. Más érterületeket is ellátó erek esetén fontos az oldalágaktól distalisabb katéterpozíciót találni és ügyelni arra, hogy az embolisatiós anyag lassú adagolásával elkerüljük annak visszaáramlását [19, 20].

\section{Szövődmények}

Az ABE szövődményeit elsősorban a más mellkasi képleteket ellátó erek járulékos embolisatiója okozza. A bronchialis artéria a nyelőcső, a nagyerek, a bronchusok

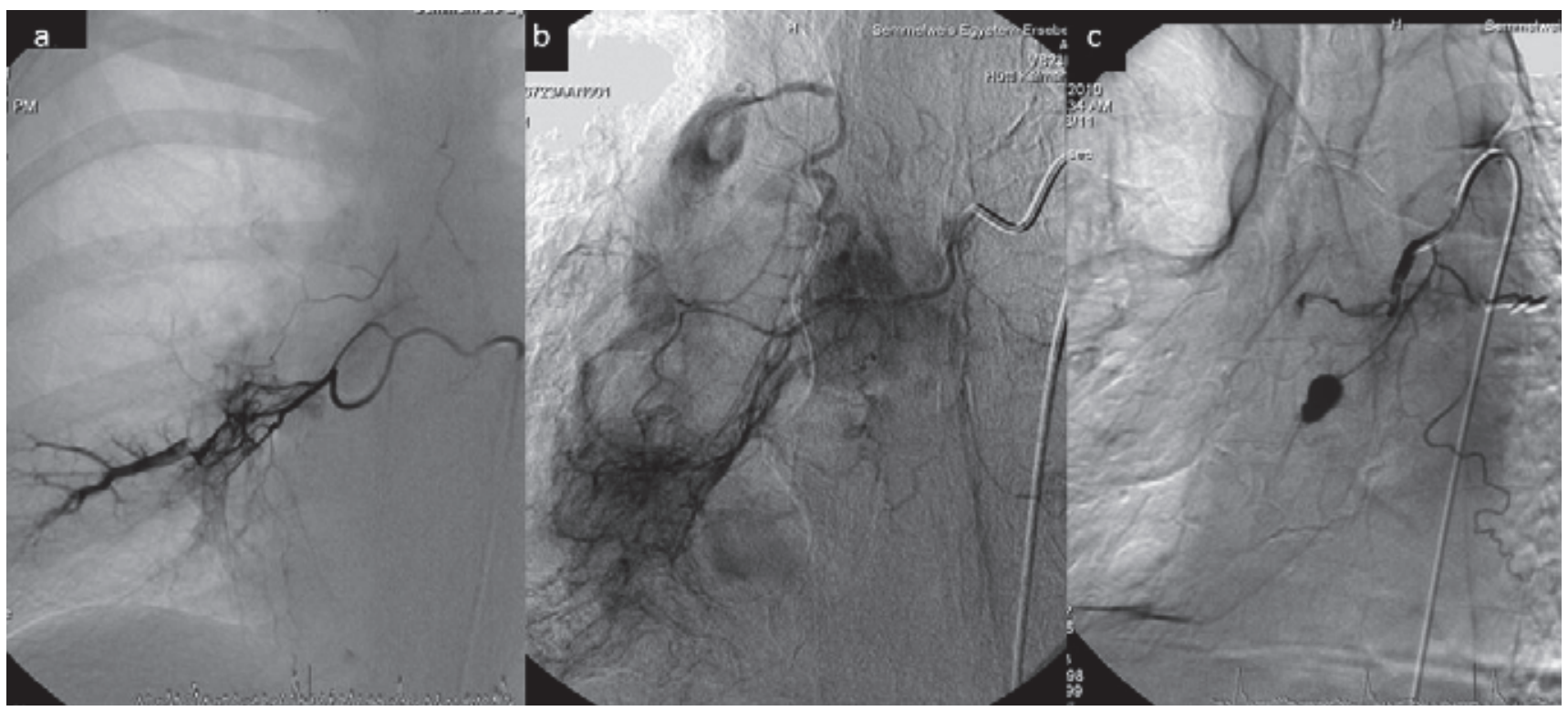

7. ábra $\quad$ a) A jobb arteria bronchialis festésekor intenzíven telődik egy pulmonalis artéria. b) Hypervascularizált gócok a jobb arteria bronchialis ellátási területén. c) Extravasatio 
és a pleura vérellátását is adja. A beavatkozás utáni mellkasi fájdalom a leggyakoribb tünet (24-91\%), ritkábban dysphagia jelentkezhet (1-18\%), mindkét esetben a panaszok spontán megszûnnek. Legsúlyosabb szövődmény a gerincvelői ischaemia $(1,4-6,5 \%)$, amely a medullaris ágak figyelmetlen embolisatiójának eredménye [21, 22].

Igen ritka szövődményként leírtak bronchialis necrosist, bronchooesophagealis fistulát $[23,24]$. Előfordult kérgi vakság is, amelynek oka feltehetően nem szándékos embolisatio lehetett a bronchialis artériás rendszer és az arteria vertebralis vagy egy pulmonalis véna közötti fistulán keresztül $[25,26]$.

\section{Eredmények}

Az ABE publikált tanulmányok és saját adataink szerint a vérköpés hatásos terápiája. Az irodalmi adatok szerint a technikai sikeresség 90\%, a rövid távú klinikai sikeresség 73-99\%; a tünetek ismételt kiújulása $10-55 \%$ gyakorisággal fordul elő $[12,19,20,21,22,27,28,29]$. A korai ismételt vérzés hátterében a nem megfelelö embolisatio, illetve az összes vérzésért felelős artéria nem teljes körű azonosítása állhat, azonban rekanalizáció, angiogenesis és kollaterálisok megerősödése is ismételt vérzést okozhat. Tuberculosis, aspergillus és tüdőtumor esetében nagyobb a valószínúsége az ismételt vérzésnek. $\mathrm{Az}$ $\mathrm{ABE}$ ismétlése a primer embolisatióval összevethető eredményességet biztosít [30]. Természetesen az ABE palliatív beavatkozás, amely nem befolyásolja a betegséget okozó folyamatot. Amennyiben a vérzés ismételt embolisatióval sem kontrollálható, mellkassebészeti beavatkozásra van szükség.

Saját anyagunkban 73 beteget kezeltünk ABE-vel, összesen 93 beavatkozás történt, amely a reintervenciók számát is tartalmazza. Az esetek 15\%-ában extrabronchialis vérzésforrást kezeltünk, ami felhívja a figyelmet arra, hogy az eredményességhez a beavatkozást megfelelő diagnosztikának kell megelöznie. Technikai sikerességünk 94,6\% volt, major szövődmény nélkül. Az elérhető 54 beteg $(75 \%)$ átlagosan 28 hónapos utánkövetése során 46 beteg $(85 \%)$ teljesen panaszmentessé vált, 6 (11\%) esetben a panaszok jelentősen csökkentek, míg 2 (4\%) beteg a beavatkozás hatástalansága miatt mútétre került.

\section{Következtetések}

A tárgyalt nem vascularis és vascularis intervenciók, embolisatiók mindegyike elérhető hazánkban. Egy részüket képzett intervenciós radiológus tudja megfelelő színvonalon és kevés szövődménnyel elvégezni, de az egyszerúbb folyadékdrenázsokat szakorvosok is végezhetik noha nem mindenhol áll rendelkezésre megfelelő gyakorlattal rendelkező szakember, illetve eszköz. Megfelelő képzéssel, szakmai kontrollal és együttmúködéssel ezen a helyzeten változtatni szükséges, a minimálisan invazív beavatkozások elérhetőségét növelni kell, mert ezzel a betegek járnak jobban. A radiológia és az inter- venciós radiológia konzultációs szakma, érdemes párbeszédet folytatni - a betegek állapotának részletesebb megismerése segítségével a kérdésekre adekvát választ adó képalkotó vizsgálatok, a problémákra egyedi, intervenciós radiológiai vagy kombinált megoldások választhatók.

Anyagi támogatás: A közlemény megírása anyagi támogatásban nem részesült.

Szerzői munkamegosztás: Mindkét szerző egyenlő arányban járult hozzá a közlemény elkészítéséhez. A cikk végleges változatát mindkét szerző elolvasta és jóváhagyta.

Érdekeltségek: A szerzőknek nincsenek érdekeltségeik.

\section{Irodalom}

[1] O’Connor, S. D., Taylor, A. T., Williams, E. C., et al.: Coagulation concepts update. Am. J. Roentgenol., 2009, 193(6), 16561664.

[2] Park, J., Charles, H. W.: Intra-abdominal abscess drainage: interval to surgery. Semin. Intervent. Radiol., 2012, 29(4), 311-313.

[3] Charles, H. W.: Abscess drainage. Semin. Intervent. Radiol., 2012, 29(4), 325-336.

[4] Mayumi, T., Someya, K., Ootubo, H., et al.: Progression of Tokyo Guidelines and Japanese Guidelines for management of acute cholangitis and cholecystitis. J. UOEH, 2013, 35(4), 249-257.

[5] Clarke, D. L., Pillay, Y., Anderson, F., et al.: The current standard of care in the periprocedural management of the patient with obstructive jaundice. Ann. R. Coll. Surg. Engl., 2006, 88(7), 610-616.

[6] Saad, W. E., Moorthy, M., Ginat, D.: Percutaneous nephrostomy: native and transplanted kidneys. Tech. Vasc. Interv. Radiol., 2009, 12(3), 172-192.

[7] Garcia-Cano, J.: Colorectal stenting as first-line treatment in acute colonic obstruction. World J. Gastrointest. Endosc., 2013, 5(10), 495-501.

[8] Covarrubias, D. A., O'Connor, O. J., McDermott, S., et al.: Radiologic percutaneous gastrostomy: review of potential complications and approach to managing the unexpected outcome. Am. J. Roentgenol., 2013, 200(4), 921-931.

[9] Crocco, J. A., Rooney, J. J., Fankushen D. S., et al.: Massive hemoptysis. Arch. Intern. Med., 1968, 121(6), 495-498.

[10] Ferris, E. J.: Pulmonary hemorrhage. Vascular evaluation and interventional therapy. Chest, 1981, 80(6), 710-714.

[11] Kalva, S. P.: Bronchial artery embolization. Tech. Vasc. Interv. Radiol., 2009, 12(2), 130-138.

[12] Fernando, H. C., Stein, M., Benfield, J. R., et al.: Role of bronchial artery embolization in the management of hemoptysis. Arch. Surg., 1998, 133(8), 862-866.

[13] Deffebach, M. E., Charan, N. B., Lakshminarayan, S., et al.: The bronchial circulation. Small, but a vital attribute of the lung. Am. Rev. Respir. Dis., 1987, 135(2), 463-481.

[14] McDonald, D. M.: Angiogenesis and remodeling of airway vasculature in chronic inflammation. Am. J. Respir. Crit. Care Med., 2001, 164(10 Pt 2), S39-S45.

[15] Remy-Jardin, M., Bouaziz, N., Dumont, P., et al.: Bronchial and nonbronchial systemic arteries at multi-detector row CT angiography: comparison with conventional angiography. Radiology, 2004, 233(3), 741-749.

[16] Pump, K. K.: Distribution of bronchial arteries in the human lung. Chest, 1972, 62(4), 447-451. 


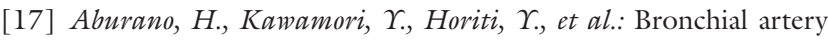
aneurysm embolization with NBCA. Cardiovasc. Intervent. Radiol., 2006, 29(6), 1141-1143.

[18] Woo, S., Yoon, C. J., Chung, J. W., et al.: Bronchial artery embolization to control hemoptysis: comparison of N-butyl-2-cyanoacrylate and polyvinyl alcohol particles. Radiology, 2013, 269(2), 594-602.

[19] Rémy, J., Arnaud, A., Fardou, H., et al.: Treatment of hemoptysis by embolization of bronchial arteries. Radiology, 1977, 122(1), 33-37.

[20] Uflacker, R., Kaemmerer, A., Neves, C., et al.: Management of massive hemoptysis by bronchial artery embolization. Radiology, 1983, 146(3), 627-634.

[21] Ramakantan, R., Bandekar, V. G., Gandhi, M. S., et al.: Massive hemoptysis due to pulmonary tuberculosis: control with bronchial artery embolization. Radiology, 1996, 200(3), 691-694.

[22] Tonkin, I. L., Hanissian, A. S., Boulden, T. F., et al.: Bronchial arteriography and embolotherapy for hemoptysis in patients with cystic fibrosis. Cardiovasc. Intervent. Radiol., 1991, 14(4), 241246

[23] Ivanick, M. J., Thorwarth, W., Donohue, J., et al.: Infarction of the left main-stem bronchus: a complication of bronchial artery embolization. Am. J. Roentgenol., 1983, 141(3), 535-537.

[24] Hsu, H. K., Su, J. M.: Giant bronchoesophageal fistula: a rare complication of bronchial artery embolization. Ann. Thorac. Surg., 1995, 60(6), 1797-1798.
[25] Van Doorn, C. S., De Boo, D. W., Weersink, E. J., et al.: Permanent cortical blindness after bronchial artery embolization. Cardiovasc. Intervent. Radiol., 2013, 36(6), 1686-1689.

[26] Peng, G., Liang, H., Ruan, L., et al.: Cortical blindness and ataxia complicating bronchial artery embolization for severe hemoptysis. Intern. Med., 2010, 49(14), 1445-1447.

[27] Hayakawa, K., Tanaka, F., Torizuka, T., et al.: Bronchial artery embolization for hemoptysis: immediate and long-term results. Cardiovasc. Intervent. Radiol., 1992, 15(3), 154-158.

[28] Mal, H., Rullon, I., Mellot, F., et al.: Immediate and long-term results of bronchial artery embolization for life-threatening hemoptysis. Chest, 1999, 115(4), 996-1001.

[29] Kato, A., Kudo, S., Matsumoto, K., et al.: Bronchial artery embolization for hemoptysis due to benign diseases: immediate and long-term results. Cardiovasc. Intervent. Radiol., 2000, 23(5), 351-357.

[30] Lee, S., Chan, J. W., Chan, S. C., et al.: Bronchial artery embolisation can be equally safe and effective in the management of chronic recurrent haemoptysis. Hong Kong Med. J., 2008, 14(1), 14-20.

(Doros Attila dr., Budapest, Baross utca 23., 1082 e-mail: doros.attila@med.semmelweis-univ.hu)

\section{Tisztelt Szerzőink, Olvasóink!}

Az Orvosi Hetilapban megjelenő/megjelent közlemények elérhetőségére több lehetőség kínálkozik.

Rendelhető különlenyomat, melynek áráról bővebben a www.akkrt.hu honlapon (Folyóirat Szerzőknek, Különlenyomat menüpont alatt) vagy Szerkesztőségünkben tájékozódhatnak.

A közlemények megvásárolhatók pdf-formátumban is, illetve igényelhető Optional Open Article (www.oopenart.com).

Adott díj ellenében az online közlemények bárki számára hozzáférhetők honlapunkon (a közlemények külön linket kapnak, így más oldalról is linkelhetővé válnak).

Bővebb információ a hirdetes@akkrt.hu címen vagy különlenyomat rendelése esetén a Szerkesztőségtől kérhető. 